\title{
The pelagic distribution of Little Auk Alle alle in relation to a frontal system off central Norway, March/April 1988
}

\author{
ARNE FOLLESTAD
}

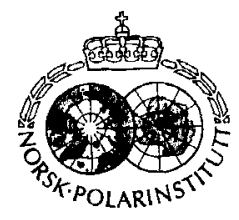

Follestad, A. 1990: The pelagic distribution of Little Auk Alle alle in relation to a frontal system off central Norway, March/April 1988. Polar Research 8, 23-28.

Large concentrations of Little Auks were recorded off central Norway in March and April 1988. Their pelagic distributional patterns may be related to the frontal system between Atlantic water and the coastal stream off central Norway. Peak densities of more than 1,000 Little Auks per $\mathrm{km}^{2}$ were recorded in two areas on the continental shelf, close to the frontal system. These densities were up to 500 times as high as those found in adjacent areas. A change in distribution with season was observed, suggesting a seasonal association with the front.

Arne Follestad, Norwegian Institute for Nature Research, Tungasletta 2, N-7004 Trondheim, Norway; February 1990.

The effects of fronts upon seabird distribution have been described by several authors (Brown et al. 1975; Haney \& McGillivary 1985a; Kinder et al. 1983). Seabirds associated with fronts or upwelling areas are often plankton feeders, such as phalaropes and storm-petrels (Briggs et al. 1984; Haney \& McGillivary 1985b). Brown (1976, 1988) found that Little Auks appeared to use frontal areas off the coast of Canada. The Little Auk is the only Atlantic alcid which feeds primarily on zooplankton, although small fish may be of importance in the winter diet (Blake 1983; Bradstreet \& Brown 1985).

Observations of seabirds have been made the last few years off the coast of central Norway, but the coverage is poor compared to the North Sea and the Barents Sea (Tasker et al. 1987; Bakken \& Mehlum 1988; Strann \& Vader 1988). Improved coverage of the seas off Norway is essential to complete an accurate description of the distribution of Little Auks in the North Sea (Tasker et al. 1987). The aim of this paper is to show that some of the distributional patterns of Little Auk in coastal waters off central Norway in late winter and spring may be related to the frontal system in this area.

\section{Oceanographic background}

The coast of central Norway is bordered by a continental shelf $(\leqslant 200 \mathrm{~m})$ which extends about
$80-90 \mathrm{~km}$ off the coast between $62^{\circ} \mathrm{N}$ and $63^{\circ} \mathrm{N}$. At its outer edge, the 'shelf-break', the continental slope drops abruptly to depths greater than $1,000 \mathrm{~m}$.

There are two important water masses along the Norwegian coast, the warm and saline Atlantic water, and the cold and less saline Norwegian coastal stream. The coastal stream originates from the Baltic stream and runs northwards along the coast of Norway, where it mixes with fresh water from rivers and oceanic water of higher salinity and density, lying outside and beneath the coastal stream (Sætre et al. 1979).

The oceanic water moves slowly when compared to the coastal stream, which attains speeds up to $100 \mathrm{~cm} / \mathrm{sec}$ ( 2 knots), and averages between 15 and $40 \mathrm{~cm} / \mathrm{sec}$. Highest speeds are normally found in the surface layers, where north winds may reverse the stream, followed by a rapid movement northwards. These high velocities usually occur some distance from the coast, often at the edge of the continental shelf (Satre et al. 1979). The two water masses meet in a frontal system, which runs along a major part of the Norwegian coast. This front may be defined broadly by large horizontal gradients of water properties such as temperature, salinity and density (see Joyce 1983; Le Fèvre 1986). Fronts where surface temperature gradients may be as high as $3-4^{\circ} \mathrm{C} / 5 \mathrm{~km}$ are not uncommon along the coast of western and central Norway during the winter ( $R$. Sætre pers. comm.). Biological characteristics of 


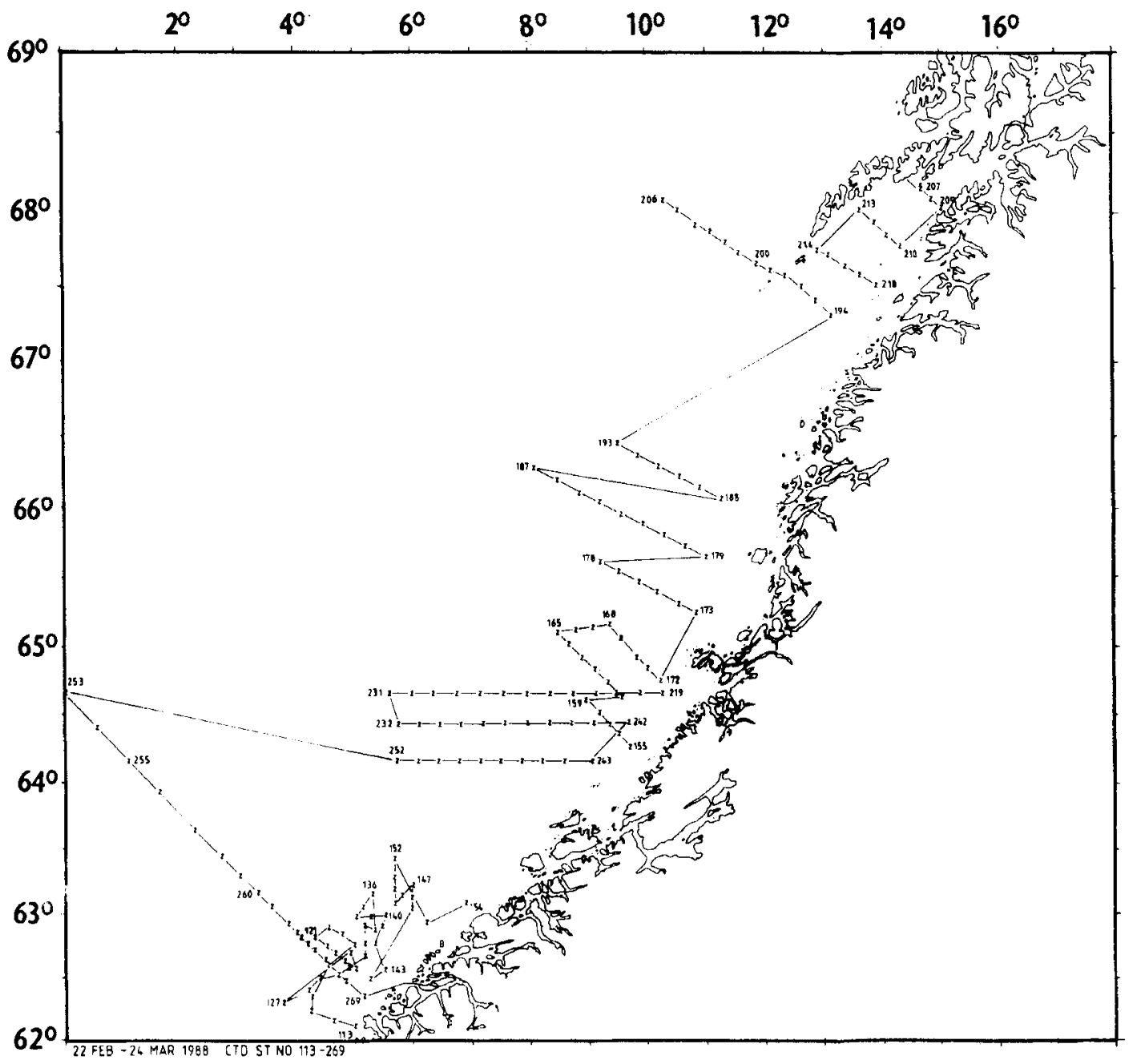

Fig. 1. Survey route of the research vessel F/F 'Eldjarn' 22 Feburary-24 March 1988. CTD stations are marked with a ' $z$ '.

frontal systems through their complex circulation patterns, such as enhanced production and accumulation of plankton, of which higher trophic animals may take advantage, are reviewed by Le Fèvre (1986).

\section{Methods and data}

The surveyed area is shown in Fig. 1. Little Auks were observed from the bridge of $F / F$ 'Eldjarn' within a $300 \mathrm{~m}$ transect while moving at a speed of 11-12 knots. Standard procedures were used
(Tasker et al. 1984) with one alteration in the procedure. Because Little Auks are difficult to observe at sea, binoculars were regularly used to scan the surface to detect Little Auks within the transect. This change in procedure may make it difficult to compare these data with those from some other surveys in the northeastern Atlantic, but this shortcoming is offset by the increase in accuracy attained.

The vertical distribution of salinity and of temperature were observed using a CTD (conductivity-temperature with depth) with a rosette sampler. 


\section{Results}

Little Auks were present mainly south of $64^{\circ} \mathrm{N}$ in a non-random distribution (Fig. 2a and b). Most Little Auks were recorded on the continental shelf, but were also found in low numbers more or less evenly distributed all the way out to the Greenwich meridian.

Maximum densities of Little Auks (10-25 birds/ $\mathrm{km}^{2}$ ) in Atlantic waters were recorded on 22 March, between CTD st. no. 252 and 253 (see Fig. 1). Some of these concentrations of birds may have been related to an eddy in the water, but no data on plankton, fish or hydrography were collected on this transect. Acoustic records indicate, however, a regular occurrence of zooplankton.

In the coastal stream, large concentrations of up to 300-400 Little Auks $/ \mathrm{km}^{2}$ were found near land on 4-6 March, but no observations were made farther offshore during this period (Fig. 2a). From the middle of March they were found in high numbers on the continental shelf south of $64^{\circ} \mathrm{N}$, with few close to the coast (Fig. 2b). When areas north to $69^{\circ} \mathrm{N}$ were surveyed in the middle of March, only a few Little Auks were observed with no particular concentrations evident. At the end of March and in early April, however, very high densities of Little Auks, between 900 and $1,500 \mathrm{birds} / \mathrm{km}^{2}$, were recorded in two areas on
Table 1. Mean densities of Little Auks in two areas with very high numbers of birds. Density is calculated on the basis of a transect width of $300 \mathrm{~m}$ and a speed of 11 knots.

\begin{tabular}{llll}
\hline $\begin{array}{l}\text { Date } \\
(1988)\end{array}$ & $\begin{array}{l}\text { Duration } \\
\text { (min.) }\end{array}$ & $\begin{array}{l}\text { Number of } \\
\text { Little Auks } \\
\text { observed }\end{array}$ & $\begin{array}{l}\text { Mean density } \\
\left(\text { birds } / \mathrm{km}^{2}\right)\end{array}$ \\
\hline 23 March & 45 & 4,900 & 1,070 \\
27 March & 48 & 5,800 & 1,190 \\
\hline
\end{tabular}

the continental shelf between $62^{\circ} 30^{\prime} \mathrm{N}$ and $63^{\circ} 30^{\prime} \mathrm{N}$ (Table 1 ). The mean density of Little Auks in Atlantic water on 23 March was 1.7 birds/ $\mathrm{km}^{2}$.

On 23 March, returning from the Greenwich meridian to the coastal areas near Svinøy $\left(62^{\circ} 20^{\prime} \mathrm{N}, 5^{\circ} 16^{\prime} \mathrm{E}\right)$, salinity and temperature were measured at intervals (CTD st. no. 253-269 in Fig. 1). Close to the edge of the continental shelf there was a front between the Atlantic and coastal water with a rapid change in surface temperature $\left(7.5\right.$ to $5^{\circ} \mathrm{C}$ ) and salinity ( 35 to $33 \%$, Fig. 3). This front could also be seen on the water surface as turbulence. The number of Little Auks observed in each 10-minute period along this transect increased very rapidly at the frontal area, from almost zero to 900-1,200 birds (Fig. 3).

On 27 March, high densities were found about $100 \mathrm{~km}$ farther north, east of Buagrunnen

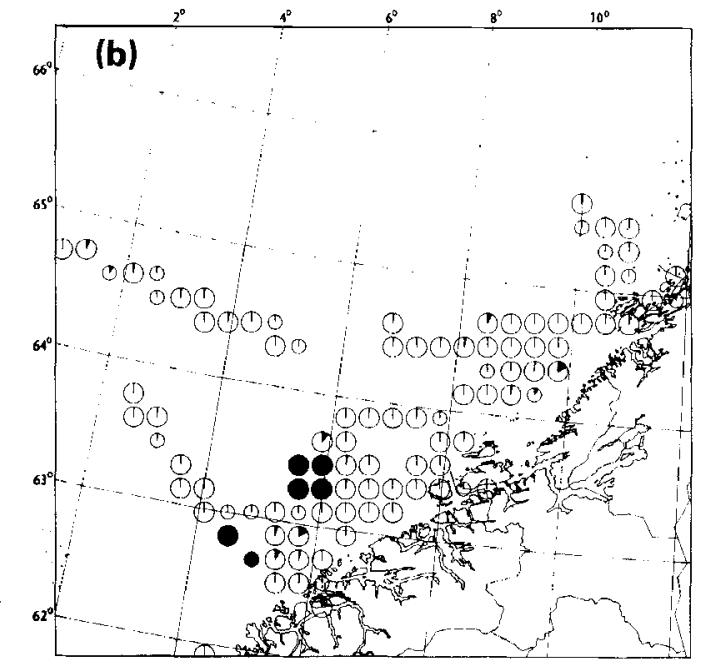

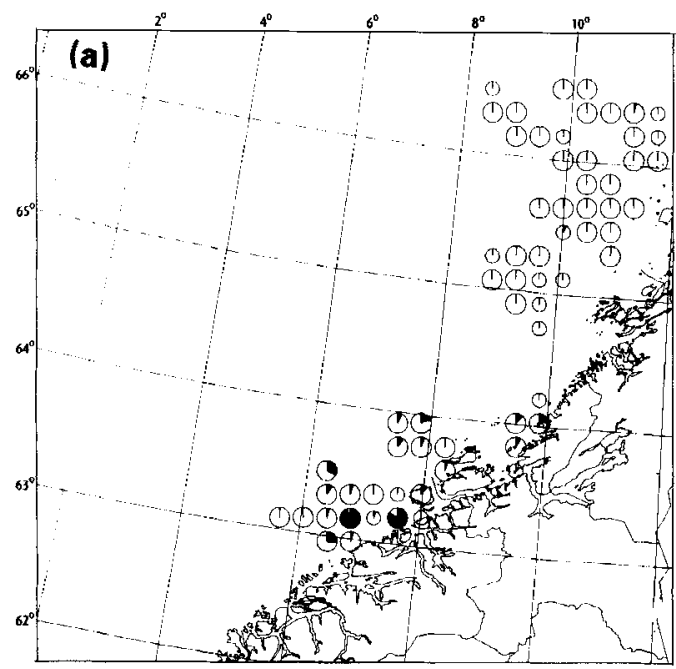

Fig. 2. (a) Distribution of Little Auks before 15 March 1988. Size of plots is $20 \times 20 \mathrm{~km}$. Filled symbols indicate a density of at least 200 birds $/ \mathrm{km}^{2}$. Small symbols represent transect lines that were less than $6 \mathrm{~km}$ long. (b) Distribution of Little Auks after 15 March 1988. 

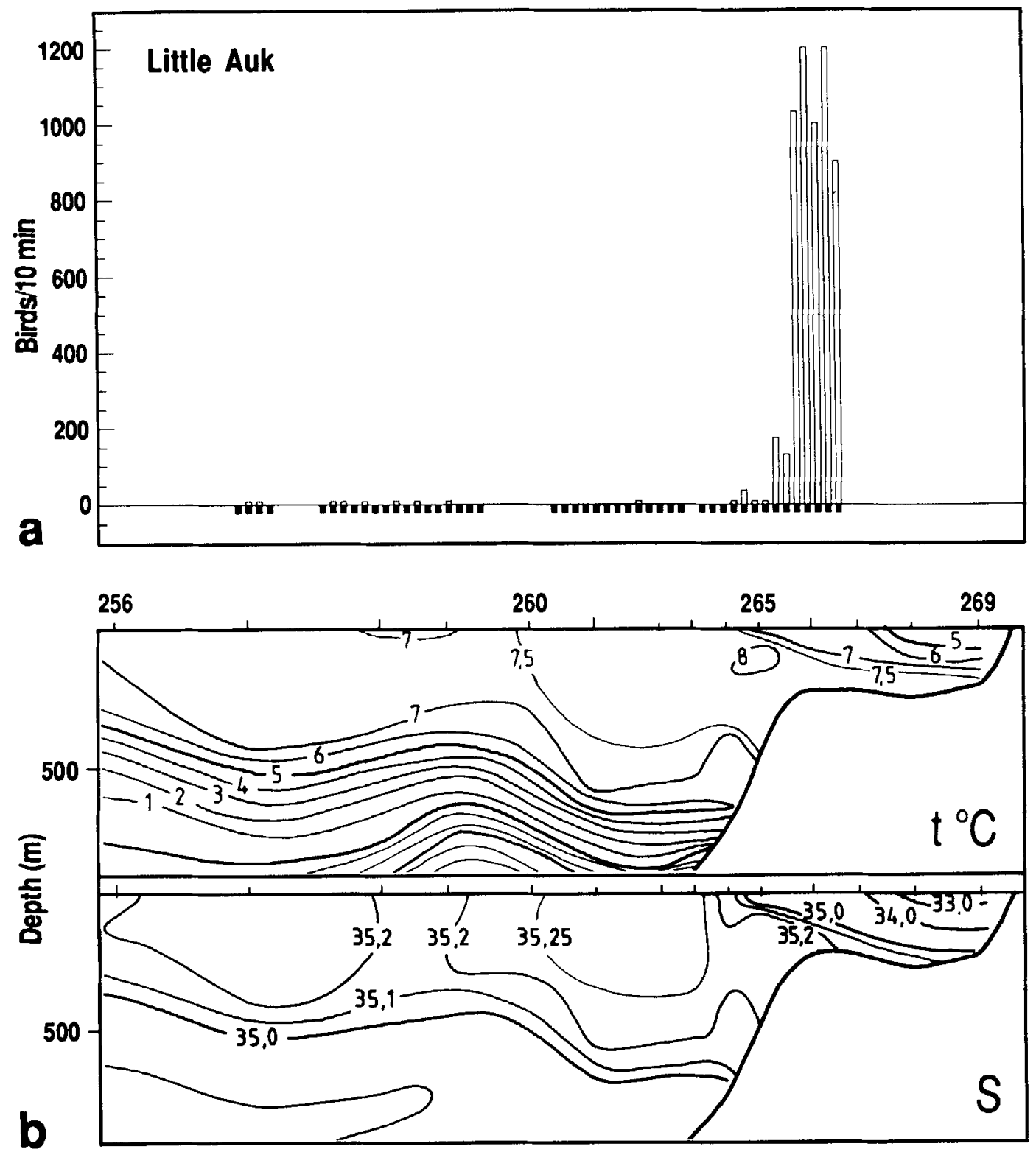

Fig. 3. (a) The number of Little Auks observed per 10-minute interval. Black squares beneath the line indicate the 10-minute intervals covered. (b) Temperature $\left(t\right.$ in ${ }^{\circ} \mathrm{C}$ ) and salinity ( $\mathrm{S}$ in \%o). CTD st. nos. are given at the top (cf. Fig. 1).

$\left(63^{\circ} 05^{\prime} \mathrm{N}, 6^{\circ} 30^{\prime} \mathrm{E}\right)$; large numbers of birds were also seen on 1 April at Buagrunnen. Buagrunnen is an important spawning area for Herring Clupea harengus, and sampling indicated a high concentration of Herring larvae present ( $R$. Sætre pers. comm.).

\section{Discussion}

The normal winter range of Little Auks in the eastern Atlantic extends south to the North Sea and Skagerrak area, as shown by surveys of seabirds at sea (see review in Brown 1985; Tasker et al. 1987) and by their presence among seabirds 
found dead after the oil spill in Skagerrak 1980/ 81 (Anker-Nilssen \& Røstad 1981). Little Auks are commonly found in the North Sea, but according to recent research only in small numbers (Tasker et al. 1987).

Little Auks are regular visitors to the Norwegian coast in winter (Norderhaug et al. 1977) where they are sometimes observed in immense numbers, even inshore. For example on 26 January 1986, 5,000 to 15,000 Little Auks were recorded (Follestad et al. 1986) between the islands of Hitra and Frøya $\left(63^{\circ} 40^{\prime} \mathrm{N}, 9^{\circ} 00^{\prime} \mathrm{E}\right)$. Large numbers of Little Auks were found close to the coast in early March 1988, with high densities only occurring at or close to the front at the continental shelf edge after 15 March.

Two different patterns of Little Auk distribution seemed to occur during March and April 1988. In the warm and saline Atlantic water, Little Auks were more or less evenly distributed in low numbers. In the cold and less saline coastal stream, or close to the frontal system between these two water masses, their distribution was patchy, and they were sometimes present in very high numbers.

More data should be collected on the distributional pattern of Little Auks along the coastline to see if they move from inshore areas to the front at certain times. The reason for the high concentrations of Little Auks associated with the frontal system off the coast of central Norway is not clear, but fronts in the North Sea often coincide with regions of increased primary production (see Le Fèvre 1986). In water off central Norway phytoplankton production in spring will at first increase at the front and in the mixed coastal water masses ( $R$. Sæatre pers. comm.). During this survey, no data on plankton or fish were collected, but acoustic observations indicated that Little Auks were concentrated where food was abundant. Little Auks may take advantage of more available food at frontal systems due to enhanced production and accumulation of zooplankton (see review by Le Fèvre 1986). There is evidence that Little Auks feed where prey is most concentrated (Bradstreet \& Brown 1985), and a better understanding of the winter and spring distribution of Little Auks off central Norway will require more detailed studies of their diet seasonally and the distribution of their prey.

Densities of 1,000-1,500 Little Auks per $\mathrm{km}^{2}$, as was observed in two areas, are exceptionally high compared to those found in the western part of the North Sea where mean densities rarely occur above 2 birds $/ \mathrm{km}^{2}$ (Tasker et al. 1987). Future studies on the Little Auk should give priority to oceanographic and biological factors that may influence the distribution of the birds at sea, as well as the impact such a huge number of birds may have on the population dynamics of zooplankton and fish.

Acknowledgements. - I thank the Norwegian Institute of Marine Research for permission to observe seabirds from their research vessel $F / F$ 'Eldjarn', the crew for their help, and $R$. Sætre for providing unpublished information on temperature and salinity. I also thank David N. Nettleship, Nancy Harrison, and Rob Barrett for comments on the manuscript. The studies were financed by the Norwegian Royal Ministry of Pctroleum and Energy.

\section{References}

Anker-Nilssen, T. \& Røstad, O. W. 1981: Undersøkelser av oljeskadede sjøfugler i forbindelse med oljekatastrofen i Skagerrak desember 1980/januar 1981. Viltrapport 16. $41 \mathrm{pp}$.

Bakken, V. \& Mehlum, F. 1988. AKUP - Final report. Seabird investigations in the Barents Sea South, north of $\mathrm{N} 74^{\circ}$ \% Bjørnøya. Norw. Polar Res. Inst. Rep. Ser. 44. 179 pp.

Blake, B. F. 1983: A comparative study of the dict of auks killed during an oil incident in the Skagerrak in January 1981. J. Zool. Lond. 201, 1-12.

Bradstreet, M. S. W. \& Brown, R. G. B. 1985: Feeding ecology of the Atlantic Alcidae. Pp. 264-318 in Nettleship, D. N. \& Birkhead, T. R. (eds): The Atlantic Alcidae. Academic Press, Orlando.

Briggs, K. J., Dettmen, K. F., Lewis, D. B. \& Tyler, B. 1984: Phalarope feeding in relation to autumn upwelling off California. Pp. 51-62 in Nettleship, D. N., Sanger, G. A. \& Springer, P. F. (eds.): Marine birds: their feeding ecology and commercial fisheries relationships. Canadian Wildlife Service Special Publication. Ottawa.

Brown, R. G. B. 1976: The foraging range of breeding Dovekics Alle alle. Canadian Field-Naturalist 90, 166-168.

Brown, R. G. B. 1985: The Atlantic Alcidae at sea. Pp. 384 427 in Nettleship. D. N. \& Birkhead, T. R. (eds): The Atlantic Alcidae. Academic Press, Orlando.

Brown, R. G. B. 1988: Oceanographic factors as determinants of the winter range of the Dovekie (Alle alle) off Atlantic Canada. Colonial Waterbirds 11, 176-180.

Brown, R. G. B., Nettleship, D. N., Germain, P., Tull, C. E. \& Davis, T. 1975: Atlas of eastern Canadian seabirds. Canadian Wildlife Service, Ottawa. $220 \mathrm{pp}$.

Follestad, A., Larsen, B. H. \& Nygård, T. 1986: Seabird and waterfowl surveys on the coast of South and North Trøndelag and southern parts of Nordland 1983-86. Viltrapport 41. 112 pp. (in Norwegian with English summary).

Haney, J. C. \& McGillivary, P. A. 1985a: Midshelf fronts in the south Atlantic Bight and their influence on seabird distribution and seasonal abundance. Biological Oceanography 3, 401-430.

Haney, J. C. \& McGillivary, P. A. 1985b: Aggregations of Cory's Shearwaters (Calonectis diomedea) at Gulf Stream fronts. Wilson Bull. 97, 191-200. 
Joyce, T. M. 1983: Varieties of ocean fronts. In Stern, M. E. \& Mellor, F. K. (eds.): Baroclinic Instability and Ocean Fronts. Technical Report 83-4I. Woods Hole Oceanographic Institution.

Kinder, T. H., Hunt, G. L., Schneider, D. \& Schumacher, J. D. 1983: Correlations between seabirds and oceanic fronts around the Pribilof Islands, Alaska. Est. Coastal and Shelf Science 16, 309-319.

Le Fève, J. 1986: Aspects of the biology of frontal systems. Advances in Marine Biology 23, 163-299.

Norderhaug, M., Brun, E. \& Møllen, G. U. 1977: Barentshavets sjøfuglressurser (Seabird resources of the Barents Sea). Norsk Polarinstitutt Meddelelser 104, 1-119.
Strann, K.-B. \& Vader, W. 1988: Registrering av sjøfugl i Barentshavet Syd. AKUP 1985-1988. Tromura, Naturvitenskap 63.47 pp. 74 maps.

Sætre, R., Sundby, S. \& Loeng, H. 1979: Endel fysiskoseanografiske trekk langs den nordlige del av norskekysten. Pp. 45-66 in Om virkninger av oljeforurensninger $i$ nordlige farvann. FoH-report 11979.

Tasker, M. L., Jones, P. H., Dixon, T. J. \& Blake. B. F. 1984: Counting seabirds at sea from ships: a revicw of methods cmployed and a suggestion for a standardized approach. Auk 101, 567-577.

Tasker, M. L., Webb, A., Hall, A. J., Pjenkowskj, M. W. \& Langslow, D. R. 1987: Seabirds in the North Sea. Nature Conservancy Council, Aberdeen. 336 pp. 